УДК 336.1

\title{
ІНВЕСТИЦІї ЯК СКЛАДОВА УПРАВЛІННЯ ОСОБИСТИМИ ФІНАНСАМИ
}

\section{INVESTMENTS AS A COMPONENT OF PERSONAL FINANCE MANAGEMENT}

\author{
Маршук Ліна Миколаївна \\ кандидат економічних наук, \\ Вінницький торговельно-економічний інститут \\ Київського національного торговельно-економічного університету \\ ORCID: https://orcid.org/0000-0003-4333-7458 \\ Клименко Марина Андріївна \\ студентка, \\ Вінницький торговельно-економічний інститут \\ Київського національного торговельно-економічного університету \\ ORCID: https://orcid.org/0000-0002-5880-5106
}

Marshuk Lina, Klymenko Marina

Vinnytsia Institute of Trade and Economics,

Kyiv National University of Trade and Economics

\begin{abstract}
У статті досліджуються інвестиції як складова управління особистими фінансами, що дозволяє збільшити власні доходи ефективніше, ніж заощадження. Дослідження засвідчує, що домогосподарства України вкладають свої тимчасово вільні кошти переважно на банківські депозити, у нерухомість та іноземну валюту, однак в цілому інвестиційні процеси в Україні розвиваються досить повільно у порівнянні із західними країнами. На основі отриманих результатів запропоновано шляхи підвищення стимулювання трансформації заощаджень населення в інвестиції шляхом формування необхідних умов та інфраструктури для ефективного фуункціонування фрінансових ринків, розробка інвестиційних продуктів, що мають високу дохідність та надійність та задовольняють різні потреби населення, підвищення ролі та значущості заощаджень у суспільстві, зміцнення соціального статусу громадян, що мають інвестиційні заощадження та правового захисту інвестиційних вкладень громадян.

Ключові слова: інвестиції, управління, особисті фрінанси, інфрляція, доходи, середня заробітна плата, банківські вклади.
\end{abstract}

В статье исследуются инвестиции как составляющая управления личными финансами, что позволяет увеличить собственные доходы эфрфективнее, чем сбережения. Исследование показывает, что домохозяйства Украины вкладывают свои временно свободные средства преимущественно на банковские депозиты, в недвижимость и иностранную валюту, однако в целом инвестиционные процессы в Украине развиваются довольно медленно по сравнению с западными странами. На основе полученных результатов предложены пути повышения стимулирования трансорормации сбережений населения в инвестиции путем формирования необходимых условий и инфраструктуры для эффрективного фрункционирования фринансовых рынков, разработка инвестиционных продуктов, имеющих высокую доходность и надежность и удовлетворяют различные потребности населения, повышение роли и значимости сбережений в обществе, укрепления социального статуса граждан, имеющих инвестиционные сбережения и правовой защиты инвестиционных вложений граждан.

Ключевые слова: инвестиции, управление, личные фринансы, инорляция, доходы, средняя заработная плата, банковские вклады.

The article examines investments as a component of personal finance management, which allows you to increase your own income more effectively than savings. The study shows that Ukrainian households invest their temporarily free funds mainly in bank deposits, real estate and foreign currency, but in general, investment processes in Ukraine are developing rather slowly compared to Western countries. The population of Ukraine chooses bank deposits to save money because they do not require large investments and are the least risky compared to other investment instruments. It was found that the main problem of investing is the distrust of Ukrainian citizens and the preference for 
savings as a more reliable way to save their own money. Demand deposits are most in demand, although the interest rates are the lowest. But the population of Ukraine chooses to invest in this deposit because the money is in free use. It was also noted that investments account for less than $10 \%$ of total household income, with the largest share of wages, pensions, scholarships, and social benefits. This indicates a lack of awareness of the benefits of investing and their lack of involvement in the investment sector. The most popular types of investment in the world are stock and currency markets. The following are the main reasons for the small share of investment in the overall structure of household budgets: reduced investment activity of households due to economic instability, inaccuracy of information about investment companies, lack of guarantees and imperfect investment insurance system, low or unstable incomes, high inflation and inflation expectations. inefficiency of the household savings system. Based on the obtained results, ways to increase the incentives for the transformation of household savings into investments by creating the necessary conditions and infrastructure for the effective functioning of financial markets, development of investment products that have high profitability and reliability and meet different needs, increase the role and importance of savings in society, social status of citizens with investment savings and legal protection of investment of citizens.

Keywords: investments, management, personal finances, inflation, incomes, average salary, bank deposits.

Постановка проблеми. Особисті фрінанси домогосподарств відіграють важливу роль у фрінансовій системі країни, оскільки нерозривно пов'язані як з публічними, так і з корпоративними. Рішення, які приймаються при управлінні особистими фрінансами, впливають на суспільні та корпоративні фрінанси, що зумовлюється участю індивідів у створенні доданої вартості, що приймає дві орорми трудову та інвестиційну. У першому випадку додана вартість створюється на підставі трудового вкладу індивіда, а грошовий еквівалент такого вкладу називається заробітною платою. У другому випадку відбувається створення заощаджень та їх інвестування у корпоративний сектор.

Аналіз останніх досліджень і публікацій. Дослідження особистих фрінансів та збалансованості фрінансових ресурсів висвітлювалося у роботах таких українських вчених, як С. Юрія, Ю. Янеля, Т. Кізими, Н. Ясинської та ін. Не дивлячись на значний інтерес зі сторони економістів, питання управління особистими фрінансами та розгляд його інструментів потребує більшого дослідження та висвітлення. Це підтверджується тим, що питома вага інвестицій та заощаджень в сукупній структурі доходів населення становить всього 5-8\%, що свідчить про недостатню теоретичну базу для управління особистими фрінансами.

Виділення невирішених раніше частин загальної проблеми. Структура доходів домогосподарств України впродовж 2009-2019 років залишилася майже незмінною. Рівень доходів $50 \%$ населення нижчий за фрактичний прожитковий мінімум. Незважаючи на те, що відбувається номінальний ріст доходів, домогосподарства витрачають близько 90\% своїх доходів, що свідчить про сталість їх матеріального становища впродовж 10 років. Це відбувається в умовах, коли заробітна плата складає більше половини усіх доходів. Саме тому актуальним $є$ пошук аль- тернативних джерел пасивних особистих доходів. Таким джерелом можуть бути інвестиції.

Формулювання цілей статті. Предметом цієї роботи є внутрішні відносини, що виникають у процесі управління особистими фрінансами та в процесі трансорормації особистих фрінансів населення у інвестиції. Метою робити є з'ясування необхідності інвестицій при управлінні особистими доходами.

Виклад основного матеріалу. Нині актуальною причиною зменшення інвестиційного потенціалу населення $\epsilon$ пандемія COVID19. У зв'язку з карантинним режимом багато домогосподарств втратили основну статтю своїх доходів, а саме заробітну плату, також затримуються пенсії, стипендії та соціальні допомоги. Внаслідок цього населення значно збідніло та прагне не примножити свої доходи за рахунок альтернативних джерел, а налагодити основні потоки надходження коштів.

Розглянемо динаміку середньої заробітної плати українців протягом останніх 10 років (табл. 1).

Таблиця 1

Динаміка середньої заробітної плати в Україні за 2011-2021 роки [1]

\begin{tabular}{|c|c|}
\hline Рік & $\begin{array}{c}\text { Рівень середньої } \\
\text { заробітної плати, грн. }\end{array}$ \\
\hline 2011 & 2639,17 \\
\hline 2012 & 3031,92 \\
\hline 2013 & 3273,82 \\
\hline 2014 & 3474,75 \\
\hline 2015 & 4207,33 \\
\hline 2016 & 5187,33 \\
\hline 2017 & 7105,42 \\
\hline 2018 & 8867,33 \\
\hline 2019 & 10503,75 \\
\hline 2020 & 11596,60 \\
\hline 2021 & 12549,00 \\
\hline
\end{tabular}


Рівень середньої заробітної плати в Україні постійно збільшується. За 10 років заробітна плата збільшилася на 9 909, 83 тис. грн., або на 475,5\%. Однак збільшення заробітної плати не свідчить про підвищення рівня життя громадян України, тому що із зростанням заробітної плати збільшувалися й ціни на товари та послуги, інсрляція та курс валюти. Незважаючи на те, що заробітна плата (основне джерело доходів) постійно збільшується, домогосподарствам не вдається досягнути високого рівня життя. Це свідчить про те, що купівельна спроможність номінальної заробітної плати $€$ низькою. Це відображається на рівні добробуту всього населення. Тож розглянемо динаміку індексу реальної заробітної плати (рис. 1).

Індекс реальної заробітної плати впродовж 10 років не мав яскраво вираженої тенденції.
Найнижчим цей показник був у 2014 році, коли індекс зменшився на 20,3\%, найбільшим - у 2017 році. Загалом показник індексу реальної заробітної плати є низьким та є відображенням великої різниці між номінальною та реальною середньою заробітною платою. Це повинно спонукати громадян України до пошуку додаткових джерел грошових ресурсів.

Однак заробітна плата не є єдиним джерелом доходів, тому розглянемо структуру ресурсів домогосподарств (рис. 2).

Найбільшу питому вагу у структурі домогосподарств становлять оплата праці та пенсії, стипендії, соціальні допомоги, надані готівкою. При чому варто зауважити, що за 10 років структура практично не змінилася. Також бачимо, що інші надходження, до яких включаються інвестиції, становлять не більше

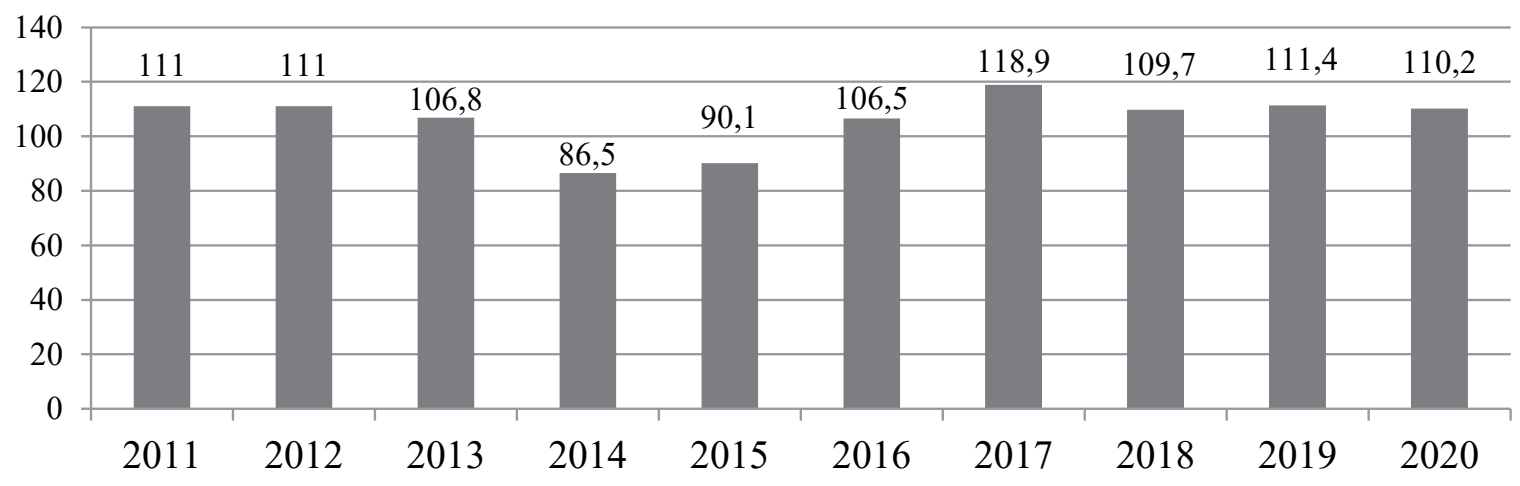

Рис. 1. Динаміка індексу реальної заробітної плати за 2011-2020 pp. [2]

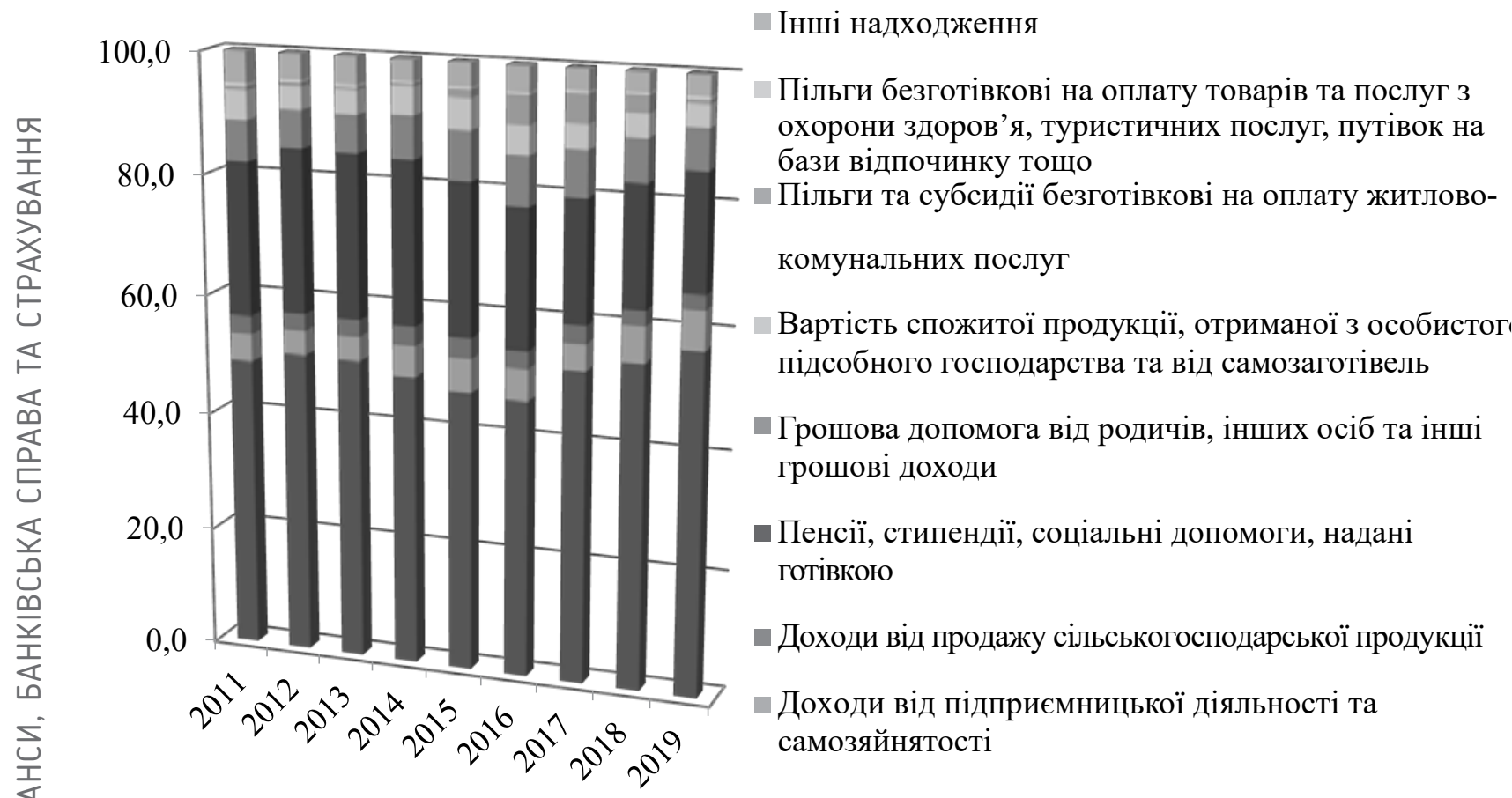

Рис. 2. Структура грошових доходів населення за 2011-2019 рр. [3] 
3-4\%, що свідчить про низьку обізнаність та недовіру населення України до вкладання грошей в інвестиції.

Проблема інвестицій полягає в тому, що їх розцінюють як витрати у той час, як в них необхідно вбачати вкладення в майбутнє. Таке розуміння інвестицій допоможе ефективніше організувати інвестиційний процес. Використання інвестицій здійснюється не лише підприємствами через реалізацію інвестиційних проектів, спрямованих на досягнення стратегічних цілей, а й домогосподарствами.

Також важливою проблемою інвестування $€$ те, що господарства частіше обирають відкладати гроші на заощадження, оскільки це надійніше та не так ризиковано, навіть не розуміючи, що заощадження з інвестиціями тісно пов'язані. Адже заощадження, як тимчасово вільні кошти, перетворюються в інвестиції, внаслідок чого домогосподарства отримують доходи від інвестицій, а також відсотки на заощаджені кошти. Грошові ресурси можуть безпосередньо вкладатися в акції, облігації підприємств або в банки чи інші інститути фрінансового ринку.

Загалом інвестиції для домогосподарств мають дві фрорми:

1) інвестиції з правом власності, до яких відносяться готівкова валюта, дорогоцінні метали в злитках, ювелірні вироби, нерухомість, антикваріат, акції й облігації на організованому вторинному фондовому ринку;

2) інвестиції без права власності, до яких можна віднести накопичувальне страхування, недержавні пенсійні фонди, банківські депозити, вклади, пайові інвестиційні фонди.

Найбільш поширеною формою залучення вільних коштів населення $€$ банківський вклад. Банки $€$ найбільш звичними установами для розміщення коштів, оскільки вони $\epsilon$ інфрормаційно відкритими, проводять зрозу- мілі рекламні кампанії та пропонують доступ до своїх послуг майже в будь-якій точці світу. Для домогосподарств вони є найбільш надійними та менш ризиковими, оскільки пропонують стабільний дохід. Також важливою перевагою банків $€$ Фонд гарантування вкладів орізичних осіб, що гарантує безумовне повернення вкладу при будь-яких кризових явищах.

Також вкладання коштів на депозитний рахунок не вимагає додаткових витрат в той, як інвестування в цінні папери вимагає оплату послуги профресійного учасника ринку цінних паперів, а вкладення в накопичувальні страхові продукти потребує додаткової оплати послуг фрінансового консультанта або інших посередницьких послуг.

Розглянемо динаміку вкладів населення за 2011-2020 рр. (рис. 3).

3 рисунку 3 бачимо, що загальна сума вкладів на депозитні рахунки постійно збільшується, при чому прослідковується чітка тенденція до зменшення частки вкладів в іноземній валюті та збільшення частки вкладів в національній валюті. Також варто зауважити, що найбільшу частину грошей населення тримає на рахунках на вимогу, що видно з рисунку 4.

Депозити на вимогу користуються найбільшим попитом, а найбільше їх зростання почалося у 2018 році, причиною цього стали зміцнення гривні та привабливі відсоткові банківські ставки. Не дивлячись на те, що вклади «до запитання» $€$ найпопулярнішими, відсотки за ними найнижчі (від 6\% до 12\% річних). Однак населення обирає саме цей вид вкладів через ряд переваг, а саме: гроші на рахунку перебувають у вільному користуванні, тобто дозволено знімати кошти в межах певного ліміту, що вказується в угоді та поповнювати рахунок у будь-який час.

Строкові вклади на термін від 6 місяців $€$ більш прибутковими, оскільки банки пропону-

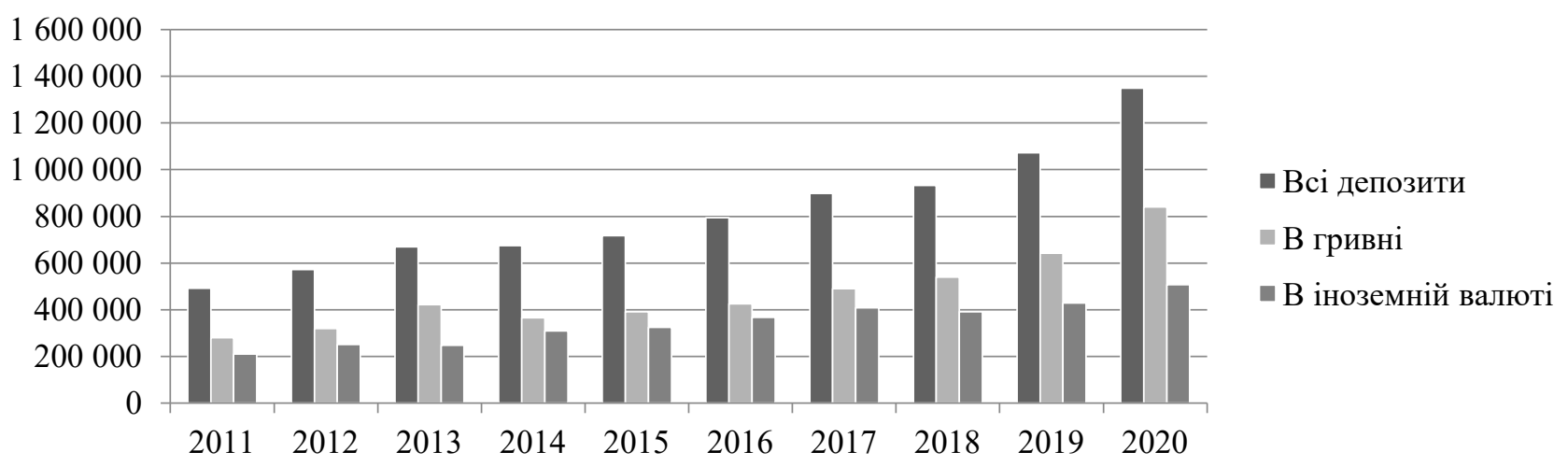

Рис. 3. Динаміка вкладів населення за 2011-2020 рр. [4] 


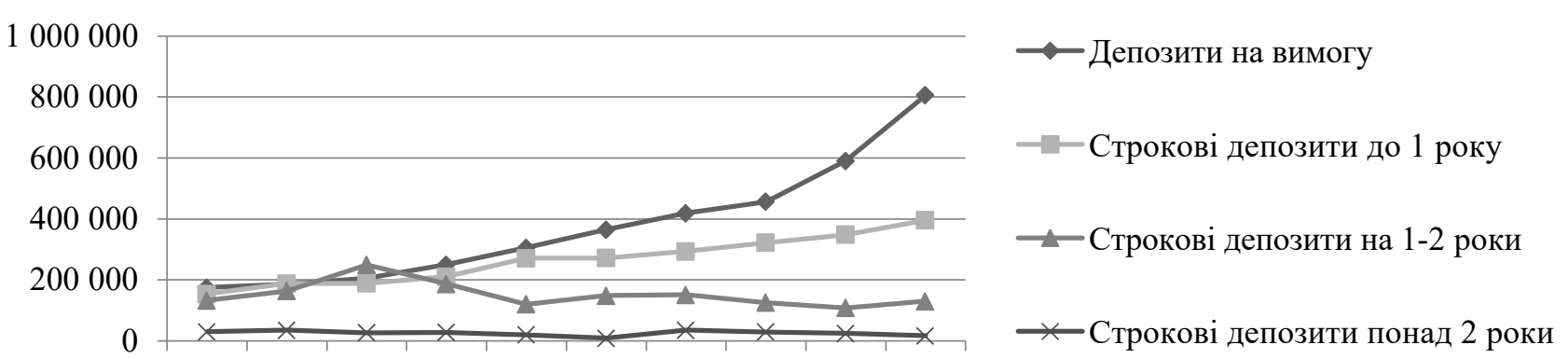

2011201220132014201520162017201820192020

Рис. 4. Динаміка за видами вкладів населення за 2011-2020 рp. [5]

ють для таких вкладів відсоткові ставки 10-17\% річних. Навіть строкові вкладення на невеликі терміни $€$ більш вигідними, ніж вклади до вимоги. Так при розміщенні коштів на 3 місяці можна отримати від 10 до 14\% річних.

Найбільші відсотки, а саме до $60 \%$ у гривні та до 20\% у валюті, пропонують такі небанківські установи, як кредитні спілки. Однак вони є більш ризикованими за банки, оскільки вони дуже ненадійні та не пропонують ніяких гарантій, на відміну від ОВдП (облігацій внутрішньої державної позики). Інвестувати гроші в ці цінні папери дуже вигідно, тому що вони $є$ достатньо прибутковими й гарантованими, тому користуються попитом не лише серед співвітчизників, а й серед іноземців.

Серед жителів зарубіжних країн популярним $\epsilon$ заробіток на фрондових ринках через купівлю-продаж акцій підприємств та дивіденди від їх діяльності. Однак в Україні ринок цінних паперів ще недостатньо розвинутий. Наприклад, середній щоденний обсяг продажів акцій на найбільш ліквідній Українській біржі не перевищує 50 млн. грн., в той час як на Варшавській фоондовій біржі обсяг продажів становить 400 млн. дол., а на НьюЙоркській досягає 120-150 млрд. грн.

Валютні ринки також $є$ джерелом отримання додатковим коштів. Наприклад, на міжбанківському валютному ринку Форекс щодня здійснюються операції на загальну суму 5 трлн. дол. Більша частина всіх операцій припадає не на фрізичних осіб, однак валютний ринок $€$ популярним варіантом серед закордонних домогосподарств, оскільки не вимагає великих вкладень та потребує лише доступу до Інтернету.

Висновки. Аналіз діючої системи перетворення персональних накопичень в інвестиції показав, що заощадження домогосподарств в організованій фрормі здебільшого ссрормовані безпосередньо за допомогою банківських вкладів. Не дивлячись на те, що фрінансовий ринок пропонує велику кількість інструментів для індивідуального інвестора, зростання залучення населення в інвестиційний процес залишається дуже повільним. Адже у часи пандемії COVID-19, коли домогосподарства масово втрачають основні потоки доходів, інвестиційний потенціал населення вкрай низький. Це викликано тим, що громадяни України прагнуть зберегти власні кошти у найбільш знайомий для них спосіб, тому найбільш вигідними для них $є$ ті інструменти, що пропонують найбільше гарантій.

Можна виділити такі основні причини та шляхи вирішення маленької частки інвестицій в загальній структурі бюджету домогосподарств:

1) Зменшення інвестиційної активності домогосподарств внаслідок економічної нестабільності. Участі населення в інвестиційному процесі сприяє стабільна економіка та економічне зростання. Для підвищення інвестиційної активності домогосподарств, необхідна система стратегічного управління інноваційно-орієнтованим соціально-економічним розвитком.

2) Недостовірність інфрормації про стан інвестиційних компаній. Компанії, що займаються інвестиційною кампанією часто не надають у повному обсязі інорормацію про поточний економічний стан. Внаслідок цього домогосподарства проявляють недовіру до цих компаній та не хочуть інвестувати тимчасово вільні кошти.

3) Відсутність гарантій та недосконала система страхування інвестицій. Саме наявність гарантій $є$ важливим фрактором, що стримує домогосподарства від трансорормації заощаджень в інвестиції. Тому від збільшення довіри українського населення у ролі інвесторів до банківського сектору зросте й загальна величина вкладень в інвестиції. 
4) Низькі або нестабільні доходи населення. Не дивлячись на те, що рівень споживання домогосподарств не зменшується, він залишається замалим у порівнянні з розвиненими країнами. Більшість населення знаходиться у ситуації, коли всі доходи витрачаються на поточне споживання, а заощадження якщо і $є$, то вкладаються у нерухомість чи валюту. Застосування диференційованого підходу до регулювання ринку фрінансових послуг дозволить вибудувати багаторівневу стратегію. Основною метою цієї стратегії повинне бути стимулювання інвестиційної діяльності домогосподарств, як заможних, так і малозабезпечених верств населення.

5) Високий рівень інсрляції та інфрляційні очікування. Населенню важко зберегти свої заощадження в умовах великої інсрляції. Інвестиційні вкладення знецінюються внаслідок високих темпів інфрляції, а середній рівень доходів від фрінансових інструментів ледве перевищують рівень інорляції. Стабілізація економіки й зниження рівня інфрляції сприятиме збільшення обсягу вкладів зі сторони індивідуальних інвесторів.

6) Неефективність системи заощаджень домогосподарств. Заощадження населення надходять у економіку у мінімальній кількості й використовуються непродуктивно. Основна частина вкладається у нерухомість. До того ж, капітал, що інвестований у вже побудовані об'єкти нерухомості «умертвляється» на тривалий період.

\section{СПИСОК ВИКОРИСТАНИХ ДЖЕРЕЛ:}

1. Динаміка середньої заробітної плати в Україні. URL: http://www.ukrstat.gov.ua/

2. Індекс реальної заробітної плати в Україні. URL: https://index.minfin.com.ua/ua/labour/salary/index/

3. Грошові доходи населення України. URL: http://www.ukrstat.gov.ua/ Банківські вклади населення України. URL: https://bank.gov.ua/ua/statistic/sector-financial/data-sector-financial

4. Банківські вклади населення України за видами. URL: https://bank.gov.ua/ua/statistic/sector-financial/datasector-financial

5. Ясинська Н.А. Управління особистими фрінансами : навчальний посібник. Львів : Видавництво Львівської політехніки, 2015. 356 с.

6. Кізима Т.О. Фінанси домогосподарств: сучасна парадигма та домінанти розвитку. Київ : Знання, 2010. 431 с.

\section{REFERENCES:}

1. Dynamika seredn'oyi zarobitnoyi platy $v$ Ukrayini [Dynamics of the average wage in Ukraine]. Available at: http://www.ukrstat.gov.ua/

2. Indeks realnoyi zarobitnoyi platy $v$ Ukrayini [Index of real wages in Ukraine]. Available at: https://index.minfin.com.ua/ ua/labour/salary/index/

3. Hroshovi dokhody naselennya Ukrayiny [Cash income of the population of Ukraine]. Available at: http://www. ukrstat.gov.ual

4. Bankivski vklady naselennya Ukrayiny [Bank deposits of the population of Ukraine]. Available at: https://bank.gov.ua/ua/statistic/sector-financial/data-sector-financial

5. Bankivski vklady naselennya Ukrayiny za vydamy [Bank deposits of the population of Ukraine by types]. Available at: https://bank.gov.ua/ua/statistic/sector-financial/data-sector-financial

6. Yasynska N.A. (2015) Upravlinnya osobystymy finansamy [Personal finance management]: navchalnyy posibnyk [tutorial]. Lviv: Vydavnytstvo Lvivskoyi politekhniky, $356 \mathrm{p}$.

7. Kizyma T.O. (2010) Finansy domohospodarstv: suchasna paradyhma ta dominanty rozvytku [Household finance: modern paradigm and dominants of development]. Kyiv: Znannya, $431 \mathrm{p}$. 